\title{
THE EFFECT OF METHYLMERCURY EXPOSURE ON ASTROCYTE OF CEREBELLAR CORTEX OF WHITE RATS (Rattus novergicus)
}

\author{
Paulus Sugianto $^{1,2}$, Sabrina Melisa Pardede ${ }^{3}$, Ngakan Made Rai Widjaja ${ }^{4}$, Widjiati $^{5}$ \\ ${ }^{1}$ Department Neurology Faculty of Medicine, Universitas Airlangga, ${ }^{2}$ Medical Staff of Dr. Soetomo Hospital, ${ }^{3}$ Faculty \\ of Veterinary Medicine, ${ }^{4}$ Department of Basic Veterinary Medicine, ${ }^{5}$ Department of Anatomy Veterinary, Faculty of \\ Veterinary Medicine, Universitas Airlangga, Surabaya, Indonesia
}

\section{ABSTRACT}

The aim of this research was to investigate the effect of different dose methylmercury (II) chloride on astrocyte in cerebellar cortex of white rat (Rattus norvegicus) exposed. This study used randomized control design using 15 adult female Wistar rats weight 180-200 $g$ of body weight. Before treatment the white rats was adapted in a week, then randomly divided into 3 groups each consist of 5 rats. $P 0$ as control were given $0.5 \mathrm{ml}$ aquades, $P 1$ and $P 2$ were given 0.1 and $0.2 \mathrm{mg} / \mathrm{kg} /$ day respectively. All groups were given treatment per oral in 30 days with sonde. The data was analyzed by ANOVA, Duncan's multiple range (Duncan's Multiple Range Test). White rats exposed by methylmercury (II) chloride, had a significant differences in the percentage of necrotic astrocyte ( $p<0.05$ ). Methylmercury chloride exposure increases the number of necrotic astrocytes on white rat.

Keywords: Methylmercury; astrocyte; necrosis; cerebellar cortex

\section{ABSTRAK}

Penelitian ini bertujuan untuk mengetahui efek paparan berbagai dosis dari metilmerkuri klorida terhadap astrosit dari kortek serebellum tikus putih (Rattus novergikus).serebellum tikus putih (Rattus novergikus). Penelitian ini merupakan penelitian acak terkontrol yang menggunakan 15 ekor tikus Wistar betina dengan berat badan 180-200 gram. Tikus diberikan adaptasi selama seminggu sebelum perlakuan, kemudian dibagi secara acak menjadi 3 group dan masing-masing group terdiri dari 5 tikus P0 sebagai control diberikan perlakuan dengan aquades sebanyak $5 \mathrm{ml}$. P1 dan P2 diberikan dengan dosis 0,1 mg/kg BB/hari. Semua group diberikan perlakuan dengan sonde selama 30 hari. Data dianalisa dengan ANOVA, Duncan's multiple range. Tikus putih yang terekspose dengan metilmerkuri klorida mempunyai perbedaan yang signifikan dalam persentase astrosit yang mengalami nekrosis ( $p<0.05)$. Paparan metilmerkuri klorida meningkatkan jumlah sel astrosit tikus putih yang mengalami nekrosis.

Kata kunci: Metil merkuri; astrosit; nekrosis; korteks serebellum

Correspondence: Paulus Sugianto, Department Neurology, Faculty of Medicine, Universitas Airlangga, Surabaya, Indonesia. Phone : +628989359888. E-mail : paulus.sugianto@gmail.com

pISSN:2355-8393 • eISSN: 2599-056x • doi: http://dx.doi.org/10.20473/fmi.v55i2.14343

- Fol Med Indones. 2019;55:122-126 • Received 30 Jan 2019 • Accepted 23 May 2019

- Open access under CC-BY-NC-SA license • Available at https://e-journal.unair.ac.id/FMI/

\section{INTRODUCTION}

Mercury is toxic pollutant, prevalent widespread and persistent in the environment. Mercury is characterized as a highly malleable liquid at normal temperature and pressure (Bernhoft 2012). Its use in many products and its emission from combustion processes have resulted in well-documented instances of population poisonings, high-level exposures of occupational groups, and worldwide chronic, low-level environmental exposures (NRC 2000).

Methylmercury is structurally the simplest form of the organic mercurial; it bioaccumulates in certain species of fish, some of which are important human and wildlife foods. There are three primary forms: elemental, inorganic and organic, each with its own distinctive character (Peterson \& Talcott 2006). There are several organic mercury compounds; however, by far the most common in the environment and in the food chain is methylmercury. Methylmercury is organic mercury which is always a serious concern in toxicology. Among organic forms, the most toxic is methylmercury (Alexander et al 2008). Most human exposure to mercury is caused by outgassing of mercury from dental amalgam, ingestion of contaminated fish, or occupational exposure (Richardson 1996). Exposure to mercury - even small amounts - may cause serious 
health problems, and is a threat to the development of the child in utero and early in life.

The original environmental concerns about mercury related to the outbreaks of neurological disease in Japan in the village of Minamata, where between 70-150 tons of mercury were discharged into the coastal fishing water of Minamata bay. In fresh and salt water, bacteria convert mercury into toxic methylmercury, which primarily attacks the central nervous system. As levels of mercury ingested from fish become a concern, the Food and Drug Association (FDA) set a maximum level of one part mercury per million part seafood (1ppm), which is the same as $1 \mu \mathrm{g}$ mercury in every gram of seafood (Timberlake 2009).

Fish based diets therefore represent a potential source of mercury exposure for dogs and cats. There are many commercial and prescription veterinary diets that contain fish. Fish oil supplement are also frequently used in therapeutic regiments for a variety of conditions for dogs and cats (Peterson \& Talcott 2006). Methyl mercury is easily absorbed through the gut and deposits in many tissues, but does not cross the blood-brain barrier as efficiently as elemental mercury; however, on entering the brain it is progressively demethylated to elemental mercury (Berlin et al 2007).

Brain tissue is a heterogeneous system comprising of two distinct compartments known as neurons and glia. The glial cells play a significant role by supplying neurons with a number of metabolites and precursors (Kaur 2008). They also have a role in maintaining thigh junction of capillaries that form the blood-brain barrier (Ross \& Pawlina 2010). In mammalian CNS, astrocytes are known as a preferential site of methylmercury accumulation and a main target of toxicity. Methylmercury preferentially accumulates in astrocytes and inhibits uptake systems for glutamate and cysteine transport, both of which will compromise glutathione $(\mathrm{GSH})$ synthesis and redox status in astrocytes (Hurtado et al 2008). Reduced GSH only neutralizes the ROS overflow. Presumably, this occurs downstream from the ROS activity responsible for the critical step in necrotic cell death (Fiers et al 1999).

Methylmercury depolarizes the presynaptic membrane which increases the $\mathrm{Na} 2+$ and decreases $\mathrm{K}+$ ion concentration. This causes disruption of $\mathrm{Ca} 2+$ homeostasis leading to increased intracellular $\mathrm{Ca} 2+$ concentration (Kaur 2008).

The cerebellum is responsible for involuntary control of balance, posture and coordination of movement. It attempt to maintain equilibrium and balance on receiving sensory information from portions of the inner ear, as well as visual and proprioceptive input. The bulk of cerebellum is composed of white matter, with a thin layer of gray matter on the surface (Christenson 2009). The gray matter of the cerebellum (cerebellar cortex) forms the periphery of this portion of the brain. Neuron within this tissue is involved in directing activities associated with vestibulation (balance), skeletal muscle and joints as well as spontaneously from cerebellar nuclei.

Methylmercury generally accumulates in the central nervous system and is found most widely in the cortex and cerebellum. The most sensitive part of brain to methylmercury are cerebral cortex (especially visual cortex) and granular membrane of cerebellum (Ganiswara et al 1995). Brain of patient with Minamata disease in Japan demonstrated unintegrated cerebellar cortex neuron because of consumption of raw fish exposed to mercury (Widowati et al 2008). Methylmercury exposure symptoms are mostly neurological, such as impaired vision, ataxia, paresthesia, neurasthenia, hearing loss, dysarthria, mental retardation, tremor, motor impairment, paralysis and death (Ganiswara et al 1995, Bernhoft, 2012). Some patients also experience delayed reaction time, poor fine motor control, and deficits in mental concentration, vocabulary, task switching, and the One Hole test, as well as mood lability (Echeverria et al 1995)

Based on the background described above the researcher the researcher conducted a study about the percentage of necrotic astrocyte in the cerebellar cortex of white rats (Rattus norvegicus) exposed to different dose of methylmercury chloride.

\section{MATERIAL AND METHODS}

\section{Setting}

This study was conducted at 2 sites, i.e. Departement of Embryology, Faculty of Veterinary and Department of Anatomy and Hystology, Faculty of Medicine, Universitas Airlangga, Surabaya.

Fifteen adult female Wistar rats (Rattus norvegicus) weighed $180-200 \mathrm{~g}$ purchased at a breeder in Batu, Malang. Fifteen adult female Wistar rats were placed into 3 plastic cages of $30 \times 35 \times 35 \mathrm{~cm}$ in size. Each had five animals, and were adapted in the same relative condition for a week, and fed with chicken pellet and given drink of tap water. One week later the subjects were weighed and randomly divided into three groups, consist of: P0: the rats were given $0.5 \mathrm{ml}$ aquades orally in 30 days, P1: methylmercury (II) chloride 
$0.1 \mathrm{mg} / \mathrm{kg} / \mathrm{day}, \quad \mathrm{P} 2$ : methylmercury (II) chloride $0.2 \mathrm{mg} / \mathrm{kg} / \mathrm{day}$

Methylmercury (II) chloride was admistered orally via Nasogastric tube once daily at 12.00 for 30 days to see the damage from low-chronic dose in white rat brain (adapted from (Huang et al 2011)).

After 30 days, 15 adult female Wistar rats were euthanized with inhalation method by putting them inside a jar that was filled with chloroform sprayed cotton. Brain samples were collected after performing dissection on each subject brain, then inserted into plastic pot contained formalin $10 \%$. Histopathological slides were made using HE stain at Department, school of medicine, University of airlangga . The presence of necrotic (pyknosis) astrocyte in the cerebellar cortex was assessed and calculated on 5 different field of view, with magnification 400 times. Then the percentage of necrotic (pyknosis) astrocytes against necrotic cells was measured. This research used percentage parameter to reduce errors that could occur in the calculation using this formula as follows:

$\left[\begin{array}{c}\text { The amount of necrotic astrocytes } \\ \text { The amount of normal + necrotic astrocytes }\end{array}\right] \times 100 \%$

Experimental design and data analysis

This was a completely randomized designed study with 3 groups of white rats, with 3 types of treatment. Each treatment repeated 5 times. Sample size was i $\mathrm{t}(\mathrm{n}-1)=$ 15 , with $\mathrm{t}$ as the number of treatments and $\mathrm{n}$ as the number of repetitions (Kusriningrum 2010).

\section{RESULTS AND DISCUSSION}

Data obtained from research about the percentage of necrotic astrocyte in the cerebellar cortex of white rats
(Rattus norvegicus) exposed to different dose of methylmercury (II) chloride can be seen in Table 1 .

Fig. 1 shows that treatment $\mathrm{P} 2$ has the highest necrotic astrocytes mean, which is $59.43 \%$. The lowest necrotic astrocyte mean is $\mathrm{P} 00.65 \%$. Therefore, among all three treatments there are significant differences $(\mathrm{p}<0.05)$.

Histophatological view of cerebellar cortex from white rats (Rattus norvegicus) exposed by different dose of methylmercury (II) chloride showed a change, that was the increase of necrotic astrocytes. Statistical analysis showed effect of methylmercury (II) chloride on necrotic astrocytes $(\mathrm{p}<0.05)$. There was a significant difference between treatment and control. The higher dose of methylmercury (II) chloride, the greater effect coul be seen on histopathological view of astrocyte in cerebellar cortex of white rats. White rats that received treatment P2 had the highest necrotic astrocytes, which was $59.43 \pm 10.30$. The rats in $\mathrm{P} 2$ group also showed several clinical sign, like incoordination movement and difficulty in walking. As mentioned by Waldichuk (1974) that cited by Ulum (Ulum 2005), the toxic effects of mercury on the body of organisms, depend on the amount of that substance in the body, the entry point of substances and period of mercury exposure with the sensitive organ in the body. After long-term subclinical methylmercury exposure, may be a proximate toxic form of mercury responsible for the changes within the astrocyte and microglial.

The changes in the structure of the nucleus can be in the form of pyknosis, karyorrhexis and karyolysis. Karyolisis occurs when the chromatin diffuses out through the nuclear membrane so the nucleus is only seen as an empty space. Karyorrhexis is characterized by a fragmented nucleus. Pyknosis is a state where chromatin condenses, so in HE staining, the nucleus will appear darker (Herawati \& Handari 2004). In this research, author calculated the percentage of necrotic astrocytes which had piknosis.

Table 1. The mean of necrotic astrocyte in cerebellar cortex of white rats exposed by methylmercury (II) chloride in Arc $\sin \mathrm{vy}(\%)$

\begin{tabular}{cccc}
\hline \multirow{2}{*}{ Replications } & \multicolumn{3}{c}{ Necrotic Astrocyte } \\
\cline { 2 - 4 } & $\mathrm{P} 0$ & $\mathrm{P} 1$ & $\mathrm{P} 2$ \\
\hline 1 & 0 & 26.92 & 44.58 \\
2 & 0 & 20.87 & 53.71 \\
3 & 3.25 & 22.57 & 62.51 \\
4 & 0 & 20.85 & 70.23 \\
5 & 0 & 24.53 & 66.17 \\
Mean & 0.65 & 23.14 & 59.43 \\
SD & 1.45 & 2.59 & 10.30 \\
$(\mathrm{X} \pm$ SD $)$ & $0.65^{\mathrm{c}} \pm 1.45$ & $23.14^{\mathrm{b}} \pm 2.59$ & $59.43^{\mathrm{a}} \pm 10.30$
\end{tabular}

Annotation: Different superscripts in the every columns show significant differences $(\mathrm{p}<0.05)$ 


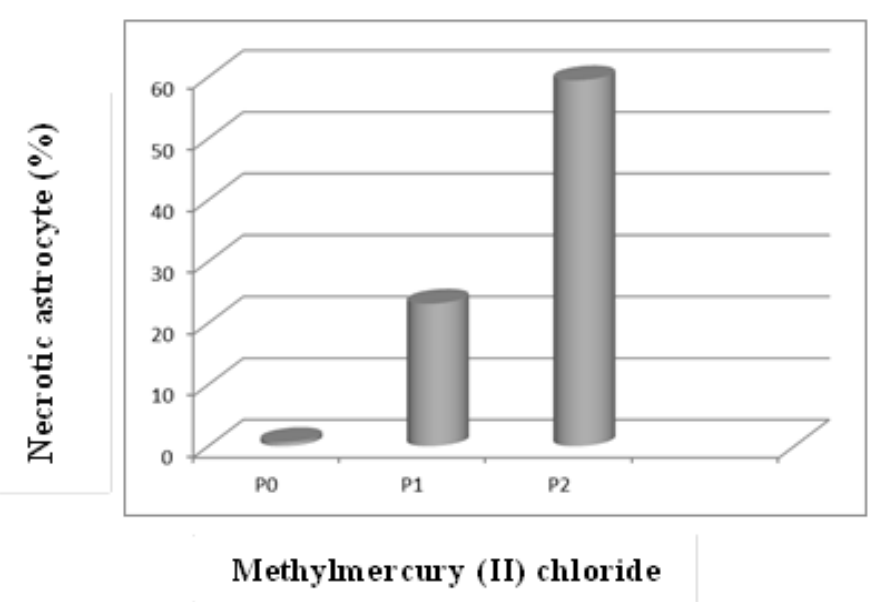

Fig. 1. Necrotic astrocyte mean in cerebellar cortex of white rats exposed to methylmercury (II) chloride (\%).

The necrotic astrocyte in the cerebellar cortex of white rats occurs because of methylmercury induce ROS and increases intracellular $\mathrm{Ca} 2+$. Calcium and reactive oxygen species (ROS) are the main players during the propagation and execution phases of necrotic cell death, directly or indirectly provoking damage to proteins, lipids and DNA, which culminates in disruption of organelle and cell integrity (Festjens et al 2006). ROS can react with biomolecules and cause oxidative damage and even necrosis (Maurino \& Flugge 2008).

Methylmercury causes a depletion of neuronal glutathione that increases the intracellular concentration of methylmercury in neurons and therefore influences the generation of ROS(Kaur et al 2006). Excessive production of ROS leads to oxidative stress, damage of intracellular molecules and organelles, and ultimately necrosis (Zong \& Thompson 2006).

In P0 groups necrotic astrocyte occured in small amounts, even though the white rats in the groups not exposed to methylmercury (II) chloride. Necrosis will occur in the development and maintenance of organismal homeostasis, and also in cellular stress, resulting from nutrient starvation or reduced oxygen supply (Zong \& Thompson 2006). According to Festjens et al. (Festjens et al 2006) necrotic cell death also occur in immune defense mechanism and physicochemical stress such as freeze-thawing or severe hyperthermia.

\section{CONCLUSION}

Methylmercury (II) chloride, can be concluded that methylmercury (II) chloride exposure can increase the number of necrotic astrocyte in cerebellar cortex of white rats. The percentage of necrotic astrocyte among all treatment showed significant differences, the highest percentage of necrotic astrocytes was obtained in group exposed to methylmercury (II) chloride $0.2 \mathrm{mg} / \mathrm{kg} /$ day, and the lowest in control group.

\section{REFERENCES}

Alexander J, Auðunsson GA, Benford DA, Cockburn JP, Cravedi E, et al (2008). Mercury as undesirable substance in animal feed. Efsa 654, 1-76

Berlin M, Zalups RK, Fowler BA (2007). Mercury in handbook on the toxicology of metals. New York, Elsevier

Bernhoft RA (2012). Mercury toxicity and treatment: a review of the literature. J environ public health 2012 , 460508

Christenson DE (2009). Veterinary medical terminology. Canada, WB Saunder Company

Echeverria D, Heyer NJ, Martin MD, Naleway CA, Woods JS, Bittner AC jr (1995). Behavioral effects of low-level exposure to elemental hg among dentists. Neurotoxicol Teratol 17, 161-8

Festjens N, Vanden Berghe T, Vandenabeele P (2006). Necrosis, a well-orchestrated form of cell demise: signalling cascades, important mediators and concomitant immune response. Biochim Biophys Acta 1757, 1371-87

Fiers W, Beyaert R, Declercq W, Vandenabeele P (1999). More than one way to die: apoptosis, necrosis and reactive oxygen damage. Oncogene 18, 7719-30

Ganiswara SG, Setiabudy R, Suyatna FD, Purwantyastuti, Nafrialdi (1995). Farmakologi dan terapi. 4th Ed. Jakarta, Fakultas Kedokteran Universitas Indonesia 
Herawati E, Handari S (2004). Pengaruh infus jamur ling zhi (Ganoderma lucidum (leyss ex fr.) Karst) terhadap mencit (Mus musculus, L.) yang diberi timbal: kajian struktur mikroanatomi Ren. Enviro 4, 55

Huang CF, Liu SH, Hsu CJ, Lin-Shiau SY (2011). Neurotoxicological effects of low-dose methylmercury and mercuric chloride in developing offspring mice. Toxicol Lett 201, 196-204

Hurtado O, Pradillo JM, Fernandez-Lopez D, Morales JR, Sobrino T, Castillo J, Alborch E, Moro MA, Lizasoain I (2008). Delayed post-ischemic administration of cdp-choline increases eaat2 association to lipid rafts and affords neuroprotection in experimental stroke. Neurobiol dis 29, 123-31

Kaur P (2008). Cellular and molecular mechanisms behind methylmercury-induced neurotoxicity. Doctor, Norwegian University of Science and Technology

Kaur P, Aschner M, Syversen T (2006). Glutathione modulation influences methyl mercury induced neurotoxicity in primary cell cultures of neurons and astrocytes. Neurotoxicology 27, 492-500

Kusriningrum RS (2010). Perancangan percobaan. Surabaya, Airlangga University Press
Maurino VG, Flugge UI (2008). Experimental systems to assess the effects of reactive oxygen species in plant tissues. Plant Signal Behav 3, 923-8

NRC (2000). Toxicological effects of methylmercury. Washington DC, National Academy Press

Peterson ME, Talcott PA (2006). Small animal toxicology. St. Louis, Missouri, United States, Elsevier Inc

Richardson M (1996). The safety of dental amalgam. Canada, Minister of Health

Ross MH, Pawlina W (2010). Hystology a text and atlas. Philadelphia, Lippincot Williams \& Willkins

Timberlake KC (2009). Chemistry: an introduction to general, organic and biological chemistry. Los Angeles, Prentice Hall

Ulum R (2005). Pengaruh pemberian merkuriklorida (hgcl2) terhadap gambaran histopathologi otak mencit (Mus musculus). Surabaya, Universitas Airlangga

Widowati W, Sastiono A, Raymond J (2008). Efek toksik logam: Pencegahan dan penanggulangan. Yogyakarta, CV Andi Offset

Zong WX, Thompson CB (2006). Necrotic death as a cell fate. Genes Dev 20, 1-15 